\title{
Urgency of Parents as Smart Parenting Against Child Education in The Industrial Revolution Era 4.0
}

\author{
Rumiati, Siska Fitri Purbayani, Tri Irmawati, Ratna Hidayah \\ Universitas Sebelas Maret \\ rrumiati49@gmail.com
}

\section{Article History}

accepted 24/09/2019 approved 01/10/2019 published 01/12/2019

\begin{abstract}
The purpose of writing this article is to examine the urgency of parents to become smart parenting in educating children in the industrial revolution era 4.0. In the era of the industrial revolution 4.0 the challenges faced by parents in educating their children are increasingly severe. The characteristics of children in this era have different characteristics from previous generations. The difference in characteristics requires parents to provide appropriate parenting strategies in improving the quality of children's education. Smart parenting is a parenting strategy that has a smart way to educate their children in order to achieve optimal development and can solve problems in their child's development. Smart parenting is suitable to be used in educating children in the industrial revolution era 4.0 because it can improve the ability of parents in terms of educating children so that they can optimally support children's development.
\end{abstract}

Keywords: Smart Parenting, Children's Education, Industrial Revolution 4.0

\begin{abstract}
Abstrak
Tujuan dari penulisan artikel ini untuk mengkaji urgensi orang tua menjadi smart parenting dalam mendidik anak di era revolusi industri 4.0. Di era revolusi industri 4.0 tantangan yang dihadapi oleh orang tua dalam mendidik anak-anaknya semakin berat. Karakteristik anak di era ini memiliki ciri khas yang berbeda dari generasi sebelumnya. Perbedaan karakteristik tersebut menuntut orang tua untuk memberikan strategi pola asuh yang tepat dalam meningkatkan mutu pendidikan anak. Smart parenting adalah strategi pola asuh orang tua yang memiliki cara cerdas dalam mendidik anaknya agar mencapai perkembangan yang optimal dan dapat memecahkan permasalahan dalam perkembangan anaknya. Smart parenting cocok digunakan dalam mendidik anak di era revolusi industri 4.0 karena dapat meningkatkan kemampuan orang tua dalam hal mendidik anak sehingga dapat mendukung secara optimal perkembangan anak. Kata kunci: Smart Parenting, Pendidikan Anak, Revolusi Industri 4.0
\end{abstract}

Social, Humanities, and Education Studies (SHEs): Conference Series https://jurnal.uns.ac.id/shes

p-ISSN 2620-9284

e-ISSN 2620-9292 


\section{PENDAHULUAN}

Keluarga merupakan lembaga pendidikan pertama bagi anak. Dalam keluarga tentunya orang tua memiliki peran yang sangat penting bagi perkembangan anak mereka. Anak akan meniru perilaku maupun sikap yang ada pada ayah dan ibunya. Karena orang tua merupakan pendidik awal bagi perkembangannya. Sebagai pendidik pertama dalam pendidikan anak tentunya orang tua harus memiliki strategi atau cara yang dapat digunakan dalam mendidik sehingga dapat memberikan bekal pengalaman kepada anak. Orang tua memiliki pengaruh yang signifikan pada perilaku anak. Keluarga diharapkan mampu membimbing anak-anak agar tumbuh menjadi pribadi yang unggul. Setiap anak memerlukan pendidikan yang layak dan bermutu demi meningkatkan taraf hidup mereka. Oleh karena itu tentu dibutuhkan lembaga pendidikan keluarga yang mampu meningkatkan mutu pendidikannya. Apalagi di zaman sekarang yang serba canggih. Banyak anak-anak yang masih tergolong usia dini sudah mulai menggunakan gadget yang tentunya hal ini dapat mempengaruhi pola pikir dan perkembangannya.

Kemajuan teknologi mampu memberikan pengaruh yang signifikan terhadap lingkungan keluarga dan masyarakat. Apalagi di era revolusi industri 4.0 informasi dan teknologi sudah mempengaruhi semua aspek kehidupan. Informasi dan pengetahuan menyebar dengan sangat mudah dan aksesibel. Revolusi Industri 4.0 merupakan kemajuan teknologi baru yang mengintegrasikan dunia fisik, digital dan biologis, dimana terdapat perubahan cara hidup kerja manusia secara fundamental (Hamdan, 2018).

Saat ini segala aktivitas sudah berbasis jaringan, pada revolusi industri ini menjadi tantangan berat bukan hanya untuk guru tetapi juga bagi keluarga. Mengingat keluarga merupakan lembaga yang tidak terikat oleh lembaga formal. Disinilah peran keluarga harus lebih di tekankan lagi. Dalam keluarga peran orang tua tidak hanya sekedar memberikan kebutuhan fisik untuk anak mereka, namun lebih dari itu di era revolusi industri 4.0 ini peran orang tua juga melibatkan aspek kebutuhan psikologis agar anak dapat menghadapi era revolusi 4.0 dengan baik. Peran pendidikan keluarga di era revolusi industri 4.0 diantaranya mengarahkan anak-anak agar dapat menghadapi tantangan dan tuntutan serta menanamkan norma susila dan nilai moral sehingga anak dapat hidup selaras dengan lingkungannya. Oleh karena itu sudah seharusnya keluarga mencari strategi yang tepat untuk memberikan pendidikan kepada anak. Keluarga harus mampu memperhatikan dan membimbing anak-anak mereka dengan baik. Namun pada kenyataannya masih banyak orang tua yang belum menyadari pentingnya pendidikan keluarga.

Seperti yang dikemukakan oleh Zahra (2019) bahwa banyak orang tua yang kurang mengetahui dan memahami bagaimana cara mendidik anak. Banyak orang tua yang kurang memperhatikan kebiasaan anak, seperti penggunaan internet sebagai alat komunikasi. Revolusi yang terjadi saat ini mendorong hadirnya berbagai macam profesi yang dulunya belum ada seperti youtuber dan blogger. Dampak penggunaan teknologi internet terhadap anak yaitu: 1) Anak dapat terkena pengaruh buruk dari internet termasuk rentan menjadi korban predator, atau bullying di dunia maya. 2) Penggunaan internet yang berlebihan dapat mempengaruhi perkembangan otak anak. 3) Anak yang kecanduan teknologi internet, perkembangan mental dan sosialnya terganggu sehingga tidak dapat bersosialisasi dengan baik. 4) Ketergantungan pada teknologi internet menyebabkan anak menjadi tidak mandiri dalam menyelesaikan masalah. 5) Kemampuan berfikir anak menjadi lamban terutama saat menghadapi situasi nyata.

Di samping itu anak memiliki sikap yang cenderung sama dengan apa yang mereka akses tanpa memperhatikan baik dan buruknya. Selain itu, penggunaan akses internet yang berlebihan juga dapat menimbulkan ketidakharmonisan dalam keluarga karena kurangnya komunikasi antara orang tua dengan anak. 
Dewasa ini, istilah smart parenting mejadi populer yang digencarkan menjadi salah satu cara yang dapat digunakan dalam meningkatkan kualitas pola asuh anak. Smart parenting adalah pola strategi orang tua untuk mendidik anak. Dimana orang tua menjadi guru pertama yang mengajari, mendidik, membina, dan membimbing. Seperti halnya dalam Pendidikan keluarga, segala usaha yang dilakukan oleh orang tua yang berupa pembiasaan dan improvisasi untuk membantu perkembangan pribadi anak (Jailani, 2014: 248). Melihat kondisi tersebut peran orangtua sebagai smart parenting menjadi salah satu cara yang dapat digunakan dalam mengembangkan mutu pendidikan. Orang tua diharapkan mampu menerapkan pola asuh yang bisa mengembangkan segala aspek perkembangan anak.

Berdasarkan penjelasan diatas dapat difokuskan permasalahan tentang bagaimana pentingnya orang tua sebagai smart parenting dapat memberikan pola pengasuhan yang tepat terhadap pendidikan anak di era revolusi industri 4.0 ini. Adapun tujuan dari penulisan artikel ini adalah untuk mengkaji pemahaman orangtua sebagai smart parenting atau dalam memberikan pengasuhan yang sesuai dengan perkembangan zaman di era revolusi industri 4.0. Manfaat dari penelitian ini diharapkan dapat memberikan pemahaman orang tua tentang cara efektif dan ideal dalam medidik anak di era revolusi industri 4.0.

\section{A Pengertian Smart Parenting}

\section{PEMBAHASAN}

Smart parenting merupakan pengasuhan cerdas oleh orangtua maupun orang dewasa dalam rangka memenuhi kebutuhan, memberi perlindungan dan mendidik anak dalam kehidupan sehari-hari dalam rangka mencapai perkembangan yang optimal (Astuti, 2013). Smart parenting juga merupakan pola strategi orang tua untuk mendidik anak. Dimana orang tua adalah guru pertama yang mengajari, mendidik, membina, dan membimbing. Seperti halnya dalam pendidikan keluarga, segala usaha yang dilakukan oleh orang tua yang berupa pembiasaan atau improvisasi untuk membantu perkembangan pribadi anak (Jailani, 2014). Sedangkan menurut Rozana, A.A (2017) smart parenting adalah pola strategi pendidikan terhadap anak, dimana orangtua sebagai madrasatul ula (sekolah pertama) mendampingi dan membimbing semua tahap pertumbuhan anak, yang merawat, melindungi, mengarahkan kehidupan baru anak dalam setiap tahapan. Dari pendapat tersebut dapat disimpulkan bahwa smart parenting adalah strategi pola asuh orang tua yang memiliki cara-cara cerdas dalam mendidik agar mencapai perkembangan anak yang optimal dan dapat memecahkan setiap permasalahan yang terkait dengan perkembangan anak.

\section{B Mengapa Smart Parenting Tepat Digunakan di Era Revolusi Industri 4.0}

Orang tua memiliki peranan yang sangat penting dalam memberikan pola pengasuhan yang tepat. Orang tua memiliki tanggung jawab dalam membentuk serta membina anak-anaknya baik dari segi psikologis maupun fisiologis. Seorang anak sangat membutuhkan bimbingan orang tuanya untuk membentuk karakter kepribadian yang baik. Sebab peran orang tua tidak hanya sekedar memberikan uang jajan atau membiayai sekolahnya tetapi orang tua juga harus berperan membentuk karakter kepribadian yang baik.

Smart Parenting tepat digunakan Di era revolusi 4.0 dikarenakan pada era ini orang tua harus benar-benar memberikan pengawasan yang tepat dari berbagai perubahan teknologi dan komunikasi yang semakin berkembang. Di samping itu generasi di era revolusi industri 4.0 memiliki karakteristik yang berbeda dengan generasi sebelumnya. Menurut Santosa (Rahmat, S. T, 2018:149) generasi anak di era revolusi industri memiliki karakteristik sebagai berikut: Pertama, memiliki ambisi besar untuk sukses. Kedua, anak cenderung berpikir praktis dan berperilaku instan (speed). Ketiga, anak mencintai kebebasan. Keempat, anak-anak yang lahir di generasi ini 
memiliki kepercayaan diri yang tinggi. Kelima, anak cenderung menyukai hal detail. Keenam, anak mempunyai keinginan yang besar untuk mendapatkan pengakuan. Ketujuh anak mahir menggunakan digital dan teknologi informasi. Perbedaan karakteristik tersebut yang menuntut orang tua untuk memberikan pola asuh yang tepat terhadap pendidikan anak dalam keluarga. Apalagi dengan adanya perkembangan teknologi dan komunikasi yang mendominasi semua bidang kehidupan.

Banyak kasus yang terjadi pada anak akibat dari adanya perkembangan teknologi dan komunikasi antara lain kegemaran anak akan penggunaan media sosial yang berlebihan akan mengurangi hubungan sosial dengan teman dan orang yang berada disekitarnya sehingga dapat menghambat kemampuan EQ (emotional quentient). Misalnya rasa soliter dan kerjasama dengan teman, kemampuan berkomunikasi sesuai waktu (Putra, R.A, dkk, 2019). Pengaruh penggunaan teknologi yang berlebihan akan menyebabkan anak menjadi tidak sabar, mereka cenderung menyukai hal-hal yang praktis. Dengan berbagai karakteristik tersebut maka diperlukan pola pengasuhan yang cerdas (smart parenting) oleh orang tua untuk meningkatkan kualitas pendidikannya yang kemudian diterapkan kepada anaknya. Oleh karena itu diperlukan adanya program parenting. Dengan program ini orang tua akan diberikan pendampingan tentang bagaimana cara mengasuh anak. Pengetahuan ini nantinya dapat di gunakan sebagai kerangka berpikir orangtua untuk diterapkan pada anak sesuai dengan tahap perkembangannya.

\section{Implementasi Orang tua sebagai Smart Parenting Dalam Pendidikan Anak}

Ada bebarapa manfaat yang di peroleh dari adanya penerapan smart parenting ini yaitu pertama, meningkatkan kemampuan orang tua dalam hal mendidik anak. Kedua, orang tua dapat menerapkan pola asuh yang tepat agar kemampuan anak dan tingkat tumbuh kembang anak meningkat, dan memberikan keterampilan pada anak dalam hal bersosialisasi dengan lingkungan sekitar. Peran orang tua sebagai smart parenting dapat dilakukan salah satunya yaitu dengan menerapkan tipe pola asuh yang sesuai.

Pola pengasuhan merupakan interaksi antara orang tua dengan anak sebagai proses sosialisasi dalam pertumbuhan dan perkembangan anak. Menurut Hurlock (Adawiah, R, 2017:35) ada beberapa tipe pola asuh anak yang digunakan orang tua antara lain: Pola Asuh Permissif menurut Hurlock (Adawiah, R, 2017:35) merupakan pola perilaku orang tua dalam berinteraksi dengan anak, yang membebaskan anak untuk melakukan apa yang ingin di lakukan tanpa mempertanyakan. Kedua, Pola Asuh Authoritarian (otoriter) Menurut Helmawati (Umairoh, S. 2018:162) Pola asuh otoriter, orang tua cenderung memberikan banyak batasan kepada anak, sehingga menyebabkan anak kurang inisiatif dan mandiri. Dan ketiga Pola asuh authoritative (demokratis) orang tua tipe ini memberikan aturan main dan disiplin kepada anak, namun memiliki gaya komunikasi yang lebih baik ketimbang authoritarian (otoriter) (Karnangsyah, E, 2017:3). Dari macam-macam pola asuh tidak semua tipe pola asuh tersebut tepat digunakan dalam pendidikan anak. Tipe pola asuh yang dapat digunakan dalam membentuk kepribadian anak yang baik yaitu tipe pola authoritative (demokratis) dimana orang tua dengan anak memiliki kerja sama yang baik. Anak diakui sebagai pribadi yang tumbuh dan berkembang.

Berdasarkan konsep pengasuhan yang di kemukakan oleh Rozana, A.A, dkk (2017) Orang tua sebagai pengasuh dapat menggunakan beberapa konsep parenting antara lain: pertama, melakukan responding artinya sebagai orang tua kita harus memberikan respon terhadap pertanyaan maupun permasalahan yang dihadapi oleh anak dengan tepat dan cepat, sehingga orang tua mampu berpikir langkah yang tepat sebelum menetapkan keputusan. Kedua, melakukan monitoring artinya orang tua harus mampu melakukan pengawasan kepada anak dalam berinteraksi dengan lingkungan sosialnya. Di mana lingkungan sosial secara langsung maupun tidak langsung memberikan pengaruh yang besar terhadap perkembangan anak. ketiga 
melakukan mentoring yaitu dengan membantu anak secara aktif untuk berperilaku sesuai dengan keinginan anak yang dirasa kegiatan tersebut positif dalam perkembangan anak. keempat modeling, yaitu orang tua harus menjadi teladan bagi anaknya. Orang tua harus menjadi contoh yang positif bagi anak mereka. Di sinilah peran orang tua sebagai smart parenting dapat di terapkan dalam pendidikan anak.

Dengan demikian dapat diketahui bahwa dalam mencapai perkembangan anak yang optimal perlu adanya pola pengasuhan atau strategi yang tepat demi meningkatkan mutu pendidikan anak yang cedas. Orang tua harus mampu bertanggungjawab untuk memberikan serta menamankan nilai-nilai moral dan keteladanan terhadap anaknya. Karena seorang anak pasti memerlukan bimbingan orang tua sehingga terciptanya kepribadian atau akhlak yang baik. Smart parenting mencakup semua tindakan yang dilakukan orang tua sebagai strategi yang cerdas dalam pola asuh terhadap anak. Sehingga terpenuhinya kebutuhan, serta mencapai perkembangan yang optimal pada anak, baik secara fisik, mental dan sosial.

\section{SIMPULAN}

Berdasarkan uraian di atas dapat di simpulkan bahwa untuk menghadapi tantangan era revolusi industri 4.0 sebagai orang tua sudah semestinya memiliki pola asuh yang efektif untuk mendidik anak. Pola asuh tersebut dapat menggunakan pola Smart Parenting. Smart Parenting adalah strategi pola asuh orang tua dalam mendidik anak dengan memiliki cara-cara cerdas agar anak mencapai perkembangan yang optimal dan dapat memecahkan setiap permasalahan yang berkaitan dengan perkembangan anak. Smart parenting cocok digunakan dalam mendidik anak di era revolusi industri 4.0 karena dapat meningkatkan kemampuan orang tua dalam hal mendidik anak sehingga dapat mendukung secara optimal perkembangan anak. Orang tua dapat menerapkan pola asuh yang tepat agar kemampuan anak dan tumbuh kembang anak meningkat, dan memberikan keterampilan pada anak agar dapat bersosialisasi dengan lingkungan sekitar. Penerapan smart parenting yang digunakan orang tua dengan menggunakan pola asuh authoritative (demokratis) dimana orang tua dengan anak memiliki kerja sama yang baik. Anak diakui sebagai pribadi yang tumbuh dan berkembang. Orang tua memberikan bimbingan dan arahan sehingga anak memiliki kontrol yang baik. Pola asuh ini memberikan kepercayaan diri yang tinggi serta membuka ruang dan kesempatan bagi anak untuk membicarakan apa yang anak inginkan.

\section{DAFTAR PUSTAKA}

Adawiah, R. (2017). Pola asuh Orang Tua dan Implikasinya Terhadap Pendidikan Anak. Jurnal Pendidikan Kewarganegaraan. Vol. 7 No.1. Bajarmasin: FKIP ULM Banjarmasin.

Astuti, H.P. (2013). Smart Parenting: Upaya Peningkatan Kemampuan Kognitif dan Kreativitas Anak Di Kelurahan Banjarjo, Boja, Kendal. Rekayasa Vol. 11 No. 2.

Hamdan. (2018). Industri 4.0: Pengaruh Revolusi Industri Pada Kewirausahaan Demi Kemandirian Ekonomi. Jurnal Nusamba Vol. 3 No.2.

Jailani, M.S. (2014). Teori Pendidikan Keluarga dan Tanggung Jawab Orang Tua dalam Pendidikan Anak Usia Dini. Jurnal Pendidikan Islam Vol. 8 No 2.

Karnangsyah, E. (2017). Hubungan Pola Asuh Orang Tua Dengan Hasil Belajar Siswa dan Implikasinya Terhadap Pelayanan Bimbingan dan Konseling. Jurnal Pendidikan Indonesia. Vol 3 No. 1:1-9. Padang: Universitas Negeri Padang.

Putra, R.A, dkk. (2019). Model Pengasuhan Keluarga Dalam Mengurangi Penggunaan Media Sosial Pada Anak. Prosiding Seminar Nasional \& Call Paper Psikologi Sosial 2019 Psikologi Sosial Di Era Revolusi Industri 4.0: Peluang \& Tantangan: Fakultas pendidikan Psikologi. 
Rozana, A.A, dkk. (2017). Smart Parenting Demokratis Dalam Membangun Karakter Anak Al-Athfal. Jurnal Pendidikan Anak. Vol. 4 No 1

Rahmat, S.T. (2018). Pola Asuh Yang Efektif Untuk Mendidik Anak Di Era Digital. Jurnal Pendidikan Dan Kebudayaan. Vol. 10 No. 2: 137-273. Flores: STKIP Santu Paulus Ruteng.

Umairoh, S. (2018). Perbedaan Pola Asuh Orang Tua Terhadap Kemandirian Anak. Jurnal IImiah Tumbuh Kembang Anak Usia Dini. Vol. 3 No. 3. Yogyakarta: Universitas islam Negeri Sunan Kalijaga Yogyakarta.

Zahra, A.C, dkk (2019). Peran Pendidikan Keluarga Dalam Menghadapi Tantangan Revolusi Industri 4.0. Prosiding Seminar Nasional \& Call Paper Psikologi Pendidikan. Malang: Universitas Negeri Malang. 